\title{
Preliminary study of the effect of dietary beta-glucan on the gut morphology of giant freshwater prawn, Macrobrachium rosenbergii
}

\begin{abstract}
The experiment was carried out on giant freshwater prawn, Macrobrachium rosenbergii in triplicate for 60 days with a dietary supplementation of beta-glucan to evaluate the effect on gut morphology. Juveniles of prawn (with initial weight of $0.34 \pm 0.01 \mathrm{~g}$ ) were fed with beta-glucan incorporated diets at levels $0,1,2$ and $3 \mathrm{~g} / \mathrm{kg}$ of feed. After 60 days the gut micrographs revealed that there were higher goblet cells, microvilli length, crypt and absorption area observed in the treatment of $1 \mathrm{~g} / \mathrm{kg}$ beta-glucan incorporated diet, however it was not significant as compared to other treatments. Less developed in control and disturbed structure were observed in levels of 2 and $3 \mathrm{~g} / \mathrm{kg}$ of beta-glucan incorporated diets. The results revealed that the diet incorporated with $1 \mathrm{~g} / \mathrm{kg}$ of beta-glucan showed development of microvillus structure and goblet cells. However higher doses of beta-glucan showed negative effects on gut morphology of Macrobrachium rosenbergii juveniles fed for 60 days.
\end{abstract}

Keywords: Beta-glucan, Gut morphology, Macrobrachium rosenbergii
Volume 4 Issue 4 - 2016

\author{
Shashikant J Meshram, Shivananda Murthy \\ H, Himanshu S Swain, Pai R, A. Ali , Harish B \\ Dhamgaye \\ Department of Aquaculture, College of Fisheries (KVAFSU), \\ India
}

Correspondence: Shashikant J Meshram, Department of Aquaculture, College of Fisheries (KVAFSU), Kankanady, Mangalore, India, Email shashikantmesh90@gmail.com

Received: July 06, 2016 | Published: September 21, 2016

\section{Introduction}

The scampi is native to Southeast Asian countries and being cultured in India, China, Bangladesh, Vietnam, Malaysia, Thailand, Taiwan, Brazil, Ecuador, and USA. But now a day's its culture decline day by day due to major constraints like diseases, feed cost, seed availability, water quality and inadequate nutrition are responsible for fluctuation of $M$. rosenbergii production. The dietary supplementation of proper nutrients helps in improving growth, survival and gut immunity of prawn. In recent day's attention has been paid for use of some nutraceuticals products derived from yeast like $\beta$-glucan, nucleotide, mannan oligosaccharide (MOS) and organic selenium as dietary supplements, which helps in promoting growth and survival in fish and shellfish. ${ }^{1,2}$ Also use of these types of prebiotics will helpful to minimize the use of antibiotics in aquaculture, which will be serving as one of the solution for eco-friendly aquaculture.

Beta-glucan is a polysaccharide derived from the cell wall of yeast and it has been used as prebiotics in poultry and swine husbandry and in aquaculture. ${ }^{3-5}$ It is demonstrated that the lactic acid bacteria (e.g. Bifidobacterium, Lactobacillus) have the ability to tolerate the acidic and bile environment of the intestinal tract. Lactic acid bacteria (LAB) also functions to convert lactose into lactic acid, thereby reducing the $\mathrm{pH}$ in the GIT and naturally preventing the colonization by many bacteria. ${ }^{6,7}$ Gastric bacterial populations may also play an important role with regard to immunostimulation and development of gut-associated lymphoid tissues. ${ }^{8}$

The importance of gut morphology have been explained in relation to scavenger organ ${ }^{9,10}$ balanced and dynamic interactions among mucus layers, intestinal epithelial cells, micro-biota and host immune defense. ${ }^{11}$ Also the disruption in the intestinal homeostasis results in the defective mucus barrier with increased permeability that results in inflammation and injury of the intestinal mucosal cells. ${ }^{11,12}$ There is little literature on effect of beta-glucan on gut morphology of fish and shellfish. Realizing the importance of nutraceutical in prawn diets, the research theme was conceptualized with objective to evaluate the effect of $\beta$-glucan on gut morphology of giant freshwater prawn Macrobrachium rosenbergii.

\section{Materials and methods}

The experiment was carried-out in triplicate for 60 days with a dietary supplementation of beta-glucan. Juveniles of $M$. rosenbergii (with initial weight of $0.34 \pm 0.01 \mathrm{~g}$ ) were fed with beta-glucan incorporated diets at levels $0,1,2$ and $3 \mathrm{~g} / \mathrm{kg}$ of feed. After 60 days of the experiment, three juveniles of prawn from each replicated treatment groups were selected and dissected out to get the gut tissues. The fixed tissues were processed using an automatic tissue processor (Shandon, Citadel 1000, England) and embedded in paraffin wax (Shandon, Histocenter 2, England). Sections were cut at 5-6 $\mu \mathrm{m}$ thickness (Weswox Dptk MT-1090A, India) and stained with haematoxylin and eosin for general morphological purposes. The tissue slides were prepared as per protocol. ${ }^{12}$ Slides were documented photographically with Olympus CX 41, Japan attached to microscope and PC. The images of different treated groups were visually analyzed and compared for the results.

\section{Results}

\section{Light microscopy of gut}

The gut morphology of prawns fed on $\beta$-glucan supplemented diets is shown in Figure 1. After 60 days of experiment there were higher goblet cells, microvilli length, crypt and absorptive area observed in $1 \mathrm{~g} / \mathrm{kg}$ beta-glucan incorporated diet group as compared to $2 \mathrm{~g} / \mathrm{kg}, 3$ $\mathrm{g} / \mathrm{kg}$ and control groups. Whereas less developed structure in control group. However disturbed structure, higher infiltrations in cells and ruptured villi structure were observed in $2 \mathrm{~g} / \mathrm{kg}$ and $3 \mathrm{~g} / \mathrm{kg}$ beta-glucan incorporated diet groups.

\section{Discussion}

The intestine is made up of a single type of epithelial cell and is considered as a scavenger organ ${ }^{9}$ and plays role in host immune 
defense system through gut. ${ }^{11,12}$ There is little literature on effect of beta-glucan on gut morphology of fish and shellfish. Kuhlwein et al. ${ }^{14}$ observed the ultrastructural changes and microbial communities in intestine by dietary supplementation of $\beta(1,3)(1,6)$-D-glucan (MacroGard) showed modulation in microbial communities and influences the morphology of the apical brush border of mirror carp, Cyprinus carpio. The channel cat fish, Ictalurus punctatus fed on 0.1 and $2 \%$ dietary supplementation of yeast polysaccharide ( $\beta$-glucan) showed significantly increased intestinal fold height and goblet cells. ${ }^{15}$ Kuhlwein et al. ${ }^{14}$ observed that there was no significant difference in intestinal absorptive area and number of goblet cells in either intestinal region of mirror carp, Cyprinus carpio fed with dietary supplemented $\beta(1,3)(1,6)$-D-glucan (MacroGard). Also observed significantly higher infiltration of leucocytes into the epithelial layer of Cyprinus carpio fed diets supplemented with $1 \%$ and $2 \%$ MacroGard $(\beta(1,3)(1,6)$-D-glucan) in the anterior intestine compared to fish fed the control and $0.1 \%$ MacroGard. Olsen et al ${ }^{17}$ reported the damaging effect of dietary prebiotics (inulin) on intestinal enterocytes in Arctic charr, Salvelinus alpines.
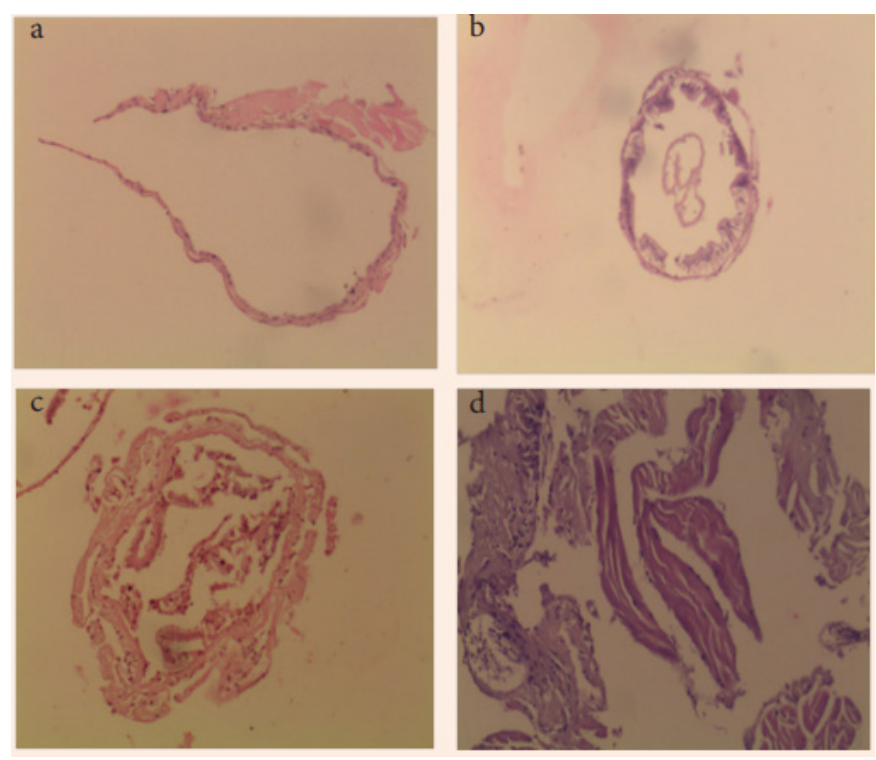

Figure I Light micrograph on gut morphology (T. S.) of Macrobrachium rosenbergii juvenile, fed diets containing $0.0,1.0,2.0$, and $3.0 \mathrm{~g} / \mathrm{kg} \quad \beta$-glucan, which are depicted as A-control, B-I.0, C-2.0 and D-3.0 treatments. (V- villi, G- goblet cells, RV- ruptured villi) [haematoxylin and eosin (H \& E) xI0].

In the present study the gut morphology of juvenile prawn fed with $1 \mathrm{~g} / \mathrm{kg}$ beta-glucan supplemented diet group showed higher goblet cells, crypt, unification and microvilli length among the treated groups, but it was not significant as compared to other groups (Figure 1). Also showed higher absorptive area, which ultimately resulted in higher growth (weight gain) than other groups. Whereas, 2 and $3 \mathrm{~g} /$ $\mathrm{kg}$ beta-glucan incorporated diet groups showed higher infilteration in cells and ruptured villi structure, may be due to excess dose of beta-glucan which accumulates in enterocytes cells of epithelial layer of intestinal region ${ }^{16,17}$ and control group showed less developed (goblet cells, crypt and microvilli) respectively, it may be due to less developments of microorganisms in gut and goblet cells. ${ }^{18,19}$ The histological gut morphology observed under present study are in agreement with the literature cited above, which suggested that prawns fed with $1 \mathrm{~g} / \mathrm{kg}$ beta-glucan incorporated diet found suitable with higher crypt, unification and microvilli length and without any detrimental effect on gut morphology of $M$. rosenbergii juvenile.

\section{Conclusion}

From the results it can be concluded that, $1 \mathrm{~g} / \mathrm{kg}$ beta-glucan incorporated diet plays role in improving goblet cells, microvilli length and absorption area in the gut of giant freshwater prawn, Macrobrachium rosenbergii for 60 days, without any detrimental effect.

\section{Acknowledgments}

None.

\section{Conflicts of interest}

None.

\section{References}

1. Masahiro S. Current research status of fish immunostimulants. Aquaculture. 1999;172(1-2):63-92.

2. Ganguly S, Paul I, Mukhopadhayay SK. Application and effectiveness of immunostimulants, probiotics and prebiotics in aquaculture: a review, Isr J Aquac Bamidgeh. 2010;62:130-138.

3. Shashidhara RG, Devegowda G. Effect of dietary mannan oligosaccharide on broiler breeder production traits and immunity, Poult Sci. 2003;82(8):1319-1325.

4. Smiricky Tjardes MR, Grieshop CM, Flickinger FA, et al. Dietary glactooligosaccharide affect ileal and total-tract nutrient digestibility, ileal and fecal bacterial concentrations and ileal fermentative characteristics og growing pigs, J Anim Sci. 2003;81:2535-2545.

5. Salze G, Maclean E, Schwarz MH, et al. Dietary mannan oligosaccharide enhances salinity tolerance and gut development of larval cobia. Aquaculture. 2008;274(1):148-152.

6. Mombelli B, Gismondo MR. The use of probiotics in medical practice, Int J Antimicrob Agents. 2000;16(4):531-536.

7. Klewicki R, Klewicka E. Antagonistic activity of lactic acid bacteria as probiotics against selected bacteria of the Enterobaceriacae family in the presence of polyols and their galactosyl derivatives, Biotechnol Lett. 2004;26(4):317-320.

8. Picchietti S, Mazzini M, Taddei AR, et al. Effects of administration of probiotics strains on GALT of larval gilthead seabream: immunochemical and ultrastructural studies. Fish Shellfish Immunol. 2007;22(1-2):57-67.

9. Wrigh SH, Ahearn GA. Nutrient absorption in invertebrates. In: Dantzler (Edr), Handbook of Physiology. Section 13, Comparative Physiology, Oxford University Press, New York, USA. 1997;pp.1137-1206.

10. Ahearn GA, Gerencser GP, Thamotharan M, et al. Invertebrate gut diverticula are nutrient absorptive organs, Am J Physiol. 1992;263:R472R481.

11. Garcia EG, Villegas JG, Mulero V. Mucosal immunity in the gut: The non-vertebrate perspective, Develop Compa Immunol. 2013;40(34):278-288.

12. Dharmani P, Srivastava V, Kissoon Singh V. Role of intestinal mucins in innate host defense mechanisms against pathogens, J Innate Immun. 2009;1(2):123-135.

13. Bullock AM. Laboratory Methods Histopathology. In: Fish Pathology. Roberts RJ \& Bailliere Tindall (Eds.), London. 1989;pp.374-384.

14. Kuhlwein H, Emery MJ, Rawling MD, et al. Effects of a dietary $\beta(1,3)$ $(1,6)$-D-glucan supplementation on intestinal microbial communities and intestinal ultrastructure of mirror carp (Cyprinus carpio L), J App . 2013;115(5):1091-106. 
15. Zhu H, Liu H, Yan J, et al. Effect of yeast polysaccharide on some hematologic parameter and gut morphology in channel catfish (Ictalurus punctatus), Fish Physiol Biochem. 2012;38(5):1441-1447.

16. Kuhlwein H, Merrifield DL, Rawling MD, et al. Effects of a dietary $\beta(1,3) \quad(1,6)-D-$ glucan supplementation on growth performance, intestinal morphology and haemato-immunological profile of mirror carp (Cyprinus carpio L.), J Anim Physiol Anim Nutr(Berl). 2013;98(2):279-289.
17. Olsen RE, Myklebust R, Kryvi H, et al. Damaging effect of dietary inulin on intestinal enterocytes in Arctic charr (Salvelinus alpines L.), Aquac Res. 2001;32(11):931-934.

18. Karam SM. Lineage commitment and maturation of epithelial cells in the gut, Front Biosci. 1999;4:D286-D298.

19. Deplancke B, Gaskins HR. Microbial modulation of innate defense: goblet cells and the intestinal mucus layer, Am J Clin Nutr. 2001;73(6):1131S-1141S. 